\title{
Ionic liquids: promising solvents for halal industry
}

\author{
*Elgharbawy, A.A.M., Azmi, N.A.N. and Mohd-Salleh, H. \\ International Institute for Halal Research and Training (INHART), International Islamic University \\ Malaysia, P.O. Box 10, 50728 Kuala Lumpur, Malaysia
}

Article history:

Received: 29 August 2019

Received in revised form: 23

October 2019

Accepted: 17 November 2019

Available Online: 10

February 2020

\section{Keywords:}

Ionic liquids,

Extraction,

Purification,

Biosensors,

Food

Halalan tayyiban

DOI:

https://doi.org/10.26656/fr.2017.4(S1).S27

\begin{abstract}
Replacement of volatile organic solvents with ionic liquids (ILs) in industrial applications is a concerned matter and a trending approach. ILs became the choice of solvents due to their merits such as low melting points $\left(<100^{\circ} \mathrm{C}\right)$ and insignificant vapor pressure. Despite being expansively investigated, ILs have not been intensively reviewed as eco-friendly solvents for the halal industry, which is the concept of this mini review. ILs have been used as surfactants, extractants for the purification of biomolecules, stabilizers for enzymes and in biosensors applications. Regardless of the lack of data on the toxicity of food products with ILs residues, low doses of ILs in in vitro tests did not lead to cell damage. Moreover, several ILs have stabilizing effects on biomolecules such as enzymes and proteins. Thus, new applications of ILs in the halal industry are feasible within the concept of halalan tayyiban (lawful and safe, good, wholesome).
\end{abstract}

\section{Introduction}

It is estimated that the global halal industry is worth multiple trillion US dollars (excluding Islamic finance) per annum and the halal industry is the fastest-growing consumer segment in the world. The global halal market is not only for 1.8 billion Muslims, but halal products are also consumed by non-Muslims. Halal products are no longer limited to food and products related to food, but extends to include medical devices, toiletries, health products, cosmetics, pharmaceuticals, as well as service sector components such as marketing, branding, logistics, packaging, print and electronic media, and financing (Dar and Nursofiza Azmi, 2010).

In line with the halal industry, efforts have been made to tackle problems in processing and handling products, particularly food, healthcare products, pharmaceuticals and machining involved in the processes. Halal industry does not focus only on the status of the product, but rather on the entire supply chain, which therefore includes ingredients utilized and all processes until the products reach the consumers. The ingredients' origins of these products are the challenging fragment of the halal supply chain. For instance, pharmaceutical products that are free from haram (unlawful) ingredients are not considered halal until they fulfil the requirements of tayyib in halal standards. Tayyib is a term given to products that meet quality standards. Generally, tayyib refers to products that are wholesome, clean, pure and produced based on standard procedures and processes. Hence, a pharmaceutical product should be clean, good and non-toxic in addition to being halal (Dar and Nursofiza Azmi, 2010).

Introducing ILs into several industrial processes has enhanced yields and productivities, and provided the additional merit of recycling. ILs are organic salts composed of ions and possess melting points below $100^{\circ}$ C. Due to their outstanding properties such as low vapor pressure and biodegradability (Ali et al., 2019), they have been in the spotlight of both scientific and industrial applications as promising substitutes to traditional volatile organic solvents from both technological and environmental perspectives (Martins et al., 2017). Apart from being involved in many industrial applications such as fuel cells (Mizumo et al., 2008) and lubricants (Bapat et al., 2018), ILs have been extensively used in the extraction and separation of biological molecules such as proteins (Lee et al., 2017), nucleic acids (Tateishi-Karimata and Sugimoto, 2018), carbohydrates (Zhao, 2019) and phenolic compounds (Ji et al., 2018). As reaction media, ILs served as effective media for reactions such as esterification (Lunagariya et al., 2017; Rajapriya et al., 2019) enzymes stabilization and activation (Elgharbawy et al., 2018), polymerization (Lunagariya et al., 2017), organic transformations (Vekariya, 2017) and isomerization (Dhar et al., 2019). 
To date, the use of ILs in food and pharmaceutical processing is not regulated by the FDA (Food and Drug Administration, USA) or any other related organization such as the European Union legislation and International Food Standards (Codex Alimentarius) (Martins et al., 2017). However, the use of ILs has promising potentials in numerous applications, which is reflected by the number of publications on ILs since 2010 until recently. Figure 1 shows the number of articles found from "Scopus" in the period 2010-2018 using the keyword, "ionic liquid" searched on $21^{\text {st }}$ October 2019. This paper is aimed to give an overview of the potential of ILs in the halal food industry and the possible applications to be considered for further investigation.

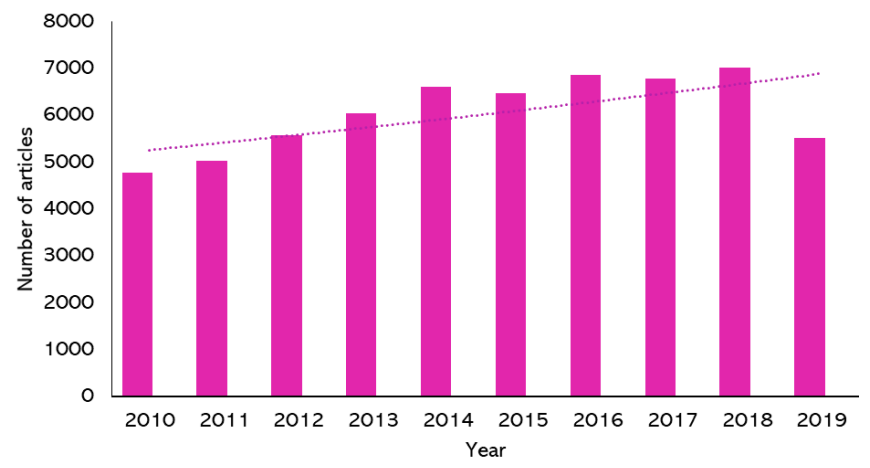

Figure 1. Number of articles found from "Scopus" in the period 2010-2019, using the keywords, "ionic liquid" as of $21^{\text {st }}$ October 2019.

\section{Ionic liquids in food industry}

\subsection{Ionic liquids as extractants}

Relevant value-added products for the food industry such as fatty acids, essential oils, phenolic compounds, and other food essences have been the prime goal of extraction. There are several advantages in terms of efficiency, recyclability, profitability and purity that have been associated with ILs as extractants, especially when ILs are combined with conventional solvents. Successful combination of solvents such as methanol, ethanol with ILs had been investigated. This is considered an important finding because ILs are usually very viscous but the reduced viscosities when mixed with low molecular solvent allows enhanced mass transfer coefficients and higher solvent penetration in the food matrices (Toledo Hijo et al., 2016). The new generations of ILs include $2^{\text {nd }}$ generation ILs that are derived from natural components, and $3^{\text {rd }}$ generation ILs that are derived from pharmaceutical ingredients are the center of attention in current research. Due to that merit and the low toxicity reported, they can be certainly suitable candidates for extraction, particularly for halal industry. ILs could be in good agreement with 'halalan tayyiban' concept as some have been reported safe and non-toxic (Martins et al., 2017). The concept of halal (lawful) and haram (unlawful) is the guidance of consumption for observant Muslims. Moreover, products that are halal to be consumed must also tayyib, signifying good nutritional quality, clean and safe (Sazelin et al., 2011). Therefore, the selection of ILs and the processing itself are crucial key factors for ensuring product safety. A few examples in the literature of ILs as extractants of food ingredients and bioactive compounds are discussed in this section.

In industrial food extraction processes, ILs are of great help as they are able to integrate chemical processes at lower temperatures compared to conventional solvents. Lower temperatures of processes lead to reduced energy costs, less thermal injuries and minimum loss of solvents by evaporation which is important for the activity of nutraceutical compounds and sensorial profiles (Toledo Hijo et al., 2016). ILs have been intensely explored in the extraction of these compounds, especially from plants. This is because of the ability of ILs to dissolve cellulose by deconstructing the intramolecular structure of cellulose and interacting with their hydroxyl groups (Pinkert et al., 2009). ILs solvation ability also allows broad range dissolution of biomass matrices which would be straightforward access to the target compounds (Ventura et al., 2017).

Trans-resveratrol from a Chinese traditional medicine herb was successfully extracted using 1-butyl-3 -methylimidazolium bromide [BMIM] $\mathrm{Br}$ ( $\mathrm{Du}$ et al., 2007). After ILs were proven effective in the extraction of bioactive compounds from plants, the number of solid -liquid extraction studies increased dramatically including ultrasound-aided extraction and microwaveaided extraction in order to improve the extraction yield. Lu et al. (2008) and Ma et al. (2010) pioneered ILs combined with microwave for the extraction of alkaloids (o-nornuciferine, $n$-nornuciferine, neferine, nuciferine, liensinine and isoliensinine) from Nelumbo nucifera, a medicinal plant. From the study, it was observed that imidazolium-based ILs, 1-butyl-3-methylimidazolium tetrafluoroborate, $[\mathrm{BMIM}]\left[\mathrm{BF}_{4}\right]$ was the most effective IL for neferine, liensinine and isoliensinine extraction. On the other hand, [BMIM]Br showed the best efficiency in the extraction of $o$-nornuciferine, $n$ nornuciferine and nuciferine compared to other ILs in the study. These studies also compared IL-microwave-aided extraction with regular microwave-aided extraction and conventional heating reflux extraction. The results indicated a plus point for the former as it possesses higher extraction efficiencies and decreases the extraction time from two hours to only $90 \mathrm{~s}$. The combination of IL aqueous solutions and microwaveassisted extraction resulted in a simple, rapid and effective extraction approach. 
Obtaining phenolic compounds from natural sources are quite complicated as the matrices are complex but ILs have been shown efficient extraction of phenolics. In the extraction of biphenyl cyclooctene lignans from the fruit of Schisandra chinensis Baill, IL-ultrasonic aided extraction was 3.5 times more efficient than that with the conventional solvent (Ma et al., 2011). Extraction time for IL-ultrasonic assisted extraction was only $30 \mathrm{mins}$ compared to 6 hours using the conventional method.

A study by Zeng et al. (2010) compared the extraction of rutin flavonoid using different types of ILs and methanol. [BMIM]Br and 1-butyl-3methylimidazolium tosylate, [BMIM][Tos] showed the highest extraction yield and the results were comparable with methanol extraction. However, methanol has few disadvantages such as volatility, flammability and negative effects on human and the environment; thus, ILs can be a better alternative. Lipid extraction using ILs is also an emerging extraction technology. Young et al. (2010) had shown a combination of 1-ethyl-3-methylimidazolium methyl sulfate, [EMIM] $\left[\mathrm{MeSO}_{4}\right]$ with methanol has a high extraction capacity of lipids from Chlorella microalgae. Choi et al. (2014) suggested that due to the synergetic effects of ILs with salts mixture, these mixtures displayed a better performance than their singular components. The combination of iron (III) chloride hexahydrate, $\mathrm{FeCl}_{3} \cdot 6 \mathrm{H}_{2} \mathrm{O}$ and 1-ethyl-3-methylimidazolium acetate, [EMIM]OAc gave extraction yields of $227.6 \mathrm{mg} / \mathrm{g}$ against $113.0 \mathrm{mg} / \mathrm{g}$ of lipids when $\mathrm{FeCl}_{3} \cdot 6 \mathrm{H}_{2} \mathrm{O}$ was used and $218.7 \mathrm{mg} / \mathrm{g}$ of lipids when only [EMIM] OAc was used. Another advantage of using ILs is the their reusability in extraction process. For example, Cláudio et al. (2013) demonstrated the recovery and reusability of [BMIM]Cl after caffeine extraction from Paullinia cupana (guaraná). The ILs aqueous solution was recovered and reused three times after the back-extraction procedure, without losing the selectivity and extraction ability. The flow diagram of the caffeine extraction process is illustrated in Figure 2.

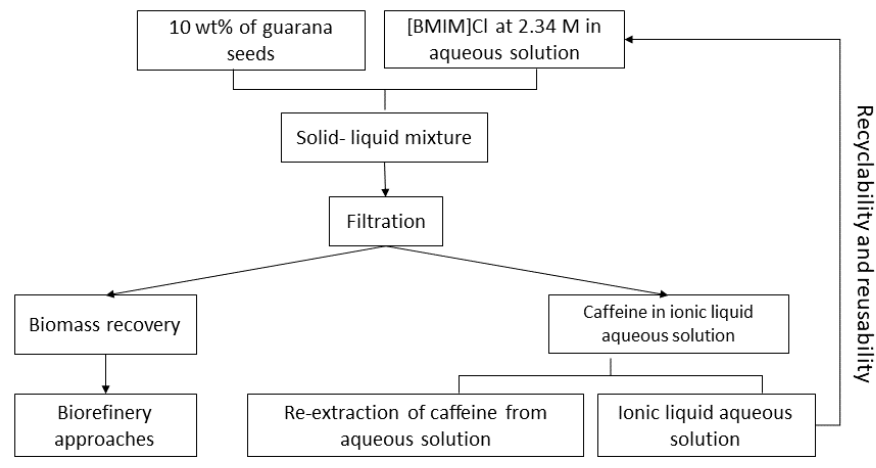

Figure 2. Flow diagram of the extraction process of caffeine using the ionic liquid 1-ethyl-3-methylimidazolium chloride [BMIM]Cl. Modified from Cláudio et al. (2013).
The examples reviewed above strongly suggest that ILs are undoubtedly able to significantly enhance the extraction efficiency using a minute quantity of solvent, at lower temperatures and reduced processing time (from hours to few minutes). Despite the need of ultrasound or microwave technologies, the increment in the extraction yield, the likelihood of reducing the environmental impact of the operation and the reduction of extraction time give enough justifications to use ILs extraction system in halal industry. Table 1 summarizes some of the uses of ILs in extraction.

\subsection{Ionic liquids as surfactants}

Surfactants are commonly defined as amphiphilic organic composites that comprise of hydrophobic and hydrophilic groups, containing oil-soluble and watersoluble components collectively, which renders them amphiphilic by nature (Bera and Belhaj, 2016). Surfactants are used in food, cosmetics, pharmaceuticals and many other industries. However, the surfactants used in most industries nowadays are usually synthetic and their bioaccumulation not only is potentially harming the environment but they are also not biodegradable (Benzagouta et al., 2013). Moreover, some of the surfactants used are derived from non-halal source and require the attention of both manufacturers and consumers. Thus, recently, interest in ILs as an alternative to conventional surfactants have risen due to their exceptional and great physicochemical properties.

One of the most studied categories of ILs as surfactants is the surface active ionic liquids (SAILs) such as choline or amino acid based ILs which possessed several advantages over other surfactants. SAILs are in their liquid form in varying degrees inclusive of room temperature, and their high viscosity increases the aqueous phase viscosities. SAILs have tuning abilities which enable them to have different characteristics, and they do not require co-surfactants considering their ability to build strong aggregates by virtue of their robust cohesive forces (Lago et al., 2012).

1-Propyl-3-alkylimidazole hydroxide [PRIm] $[\mathrm{OH}]$ was able to reduce the interfacial tension of solvent effectively and produce micelles in water. This is because $[\mathrm{PRIm}][\mathrm{OH}]$ possessed hydrophilic ion pairs and hydrophobic alkyl groups which offers excellent surface activity. The constituted micelles possess the ability to solubilize an additional number of reactants into water and adequately amplify the probability of interaction effectively between reactants and catalytic active sites (Zhang et al., 2018). Vicente et al. (2016) reported the application of aqueous micellar two-phase systems consisting of ILs as co-surfactants in extracting bromelain from pineapple stem crude extract, yielding 
Table 1. Applications of ILs in the extraction of some compounds.

\begin{tabular}{|c|c|c|c|c|}
\hline $\begin{array}{l}\text { Extraction } \\
\text { technique }\end{array}$ & Compound(s) extracted & Ionic liquid & Findings & References \\
\hline \multirow{6}{*}{$\begin{array}{l}\text { IL-based } \\
\text { ultrasonic- } \\
\text { assisted } \\
\text { extraction } \\
\text { (IL-UAE) }\end{array}$} & $\begin{array}{l}\text { Procyanidins from Larix } \\
\text { gmelinii bark }\end{array}$ & $\begin{array}{l}\text { 1-butyl-3- } \\
\text { methylimidazolium } \\
\text { bromide ([BMIM]Br) }\end{array}$ & $\begin{array}{l}\text { Relative to conventional methods, the } \\
\text { proposed approach provided higher extraction } \\
\text { efficiency, and reduced energy and time. }\end{array}$ & $\begin{array}{l}\text { (Sun et al., } \\
\text { 2013) }\end{array}$ \\
\hline & $\begin{array}{l}\text { phenolics gallic acid, } \\
\text { chlorogenic acid, rutin, } \\
\text { psoralen, and bergapten } \\
\text { from different parts of } \\
\text { fig }\end{array}$ & $\begin{array}{l}\text { 1-butyl-3- } \\
\text { methylimidazole } \\
\text { hexafluorophosphate } \\
{[\mathrm{BMIM}]\left[\mathrm{PF}_{6}\right]}\end{array}$ & $\begin{array}{l}\text { IL-UAE exhibited higher efficiency } \\
\text { compared to methanol as solvent. }\end{array}$ & $\begin{array}{l}\text { (Qin et al., } \\
\text { 2015) }\end{array}$ \\
\hline & $\begin{array}{l}\text { Antimicrobial } \\
\text { compounds from the } \\
\text { bark of Cinnamomum } \\
\text { cassia }\end{array}$ & $\begin{array}{l}\text { tris (2-hydroxyethyl) } \\
\text { methylammonium } \\
\text { methylsulfate }\end{array}$ & $\begin{array}{l}\text { The IL used the uttermost effective extraction } \\
\text { agents, which are preferable over traditional } \\
\text { solvents like ethanol, ethyl acetate, hexane, } \\
\text { dichloromethane }\end{array}$ & $\begin{array}{c}\text { (Michalczyk et } \\
\text { al., 2015) }\end{array}$ \\
\hline & $\begin{array}{l}\text { Oleanolic acid from } \\
\text { grape seeds }\end{array}$ & $([\mathrm{BMIM}] \mathrm{Cl})$ & $\begin{array}{l}\text { In comparison with the common ultrasonic- } \\
\text { assisted extraction (UAE), the recommended } \\
\text { method showed to be } 1.64 \text { times more } \\
\text { efficient. }\end{array}$ & $\begin{array}{l}\text { (Zhang et al., } \\
\text { 2017) }\end{array}$ \\
\hline & Alkaloids from cacao & $\begin{array}{l}\text { 2-hydroxy } \\
\text { ethylammonium acetate } \\
\text { (2HEAA) }\end{array}$ & $\begin{array}{l}\text { The findings proved the effectiveness of } \\
\text { protic ILs on the yields of alkaloids extracted } \\
\text { from cacao. }\end{array}$ & $\begin{array}{l}\text { (de Oliveira et } \\
\quad \text { al., 2018) }\end{array}$ \\
\hline & $\begin{array}{l}\text { Extraction of pectin from } \\
\text { lemon peels }\end{array}$ & $([\mathrm{BMIM}] \mathrm{Cl})$ & $\begin{array}{l}\text { Yield of pectin from the microwave-aided } \\
\text { extraction is much higher than conventional } \\
\text { heating reflux extraction }\end{array}$ & $\begin{array}{l}\text { (Guolin et al., } \\
\text { 2012) }\end{array}$ \\
\hline \multirow{3}{*}{$\begin{array}{l}\text { IL-microwave- } \\
\text { assisted } \\
\text { extraction } \\
\text { (IL-MAE) }\end{array}$} & $\begin{array}{l}\text { Extraction of flavonoids } \\
\text { from Bauhinia } \\
\text { championii (Benth.) } \\
\text { Benth. }\end{array}$ & ([BMIM] Br) & $\begin{array}{l}\text { Compared with the traditional heat-reflux } \\
\text { extraction (CHRE) and the conventional } \\
\text { MAE, IL-MAE possesses the ability to yield } \\
\text { a higher extraction in a shorter time. }\end{array}$ & (Xu et al., 2012) \\
\hline & $\begin{array}{l}\text { Extraction of lipids from } \\
\text { microalgae }\end{array}$ & $\begin{array}{l}\text { 1-butyl-3- } \\
\text { methylimidazolium } \\
\text { hydrogen sulfate } \\
\left([\mathrm{BMIM}]\left[\mathrm{HSO}_{4}\right]\right)\end{array}$ & $\begin{array}{l}{[\mathrm{BMIM}]\left[\mathrm{HSO}_{4}\right] \text { proved to be efficient and }} \\
\text { substantial during the extraction of lipid from } \\
\text { algae. }\end{array}$ & $\begin{array}{l}\text { (Pan et al., } \\
\text { 2016) }\end{array}$ \\
\hline & $\begin{array}{l}\text { Polyphenolic content } \\
\text { from Peperomia } \\
\text { pellucida }(\mathrm{L}) \text { kunth }\end{array}$ & $\begin{array}{l}\text { 1-butyl-3- } \\
\text { methylimidazolium } \\
\text { tetrafluoroborate } \\
\left(\left[\mathrm{BMIM} \mathrm{BF}_{4}\right)\right.\end{array}$ & $\begin{array}{l}\text { IL-MAE method is rapid, efficient and easy } \\
\text { also produced a higher extraction } \\
\text { polyphenolic }\end{array}$ & $\begin{array}{l}\text { (Ahmad et al., } \\
\text { 2017) }\end{array}$ \\
\hline
\end{tabular}

$90 \%$ bromelain recovery.

The lowest concentration of surfactant molecules needed to form micelles at a set temperature is critical micelle concentration, CMC (Mohajeri and Noudeh, 2012). Ali et al. (2019) successfully synthesized three types of SAILs that have CMC value lower than conventional ionic surfactants. The extended hydrophobic alkyl chain and the vast size gap of the cations probably provide the robust electrostatic repulsion between the charged head groups in the surface layer. Low CMC value is important, especially in food industry since low concentrations of surfactants can be incorporated into food products according to food legislation. Surfactants are utilized to enhance texture, stability, softness, aeration, and shelf life of foods. Thus, the thermodynamic constancy of emulsions alters the crystallization profile of the oil droplets and impacts the coalescence process of fat globules, which could be further improved with the abilities of surfactants and the electrostatic characteristic of ILs.

There is a mounting interest in using ILs as surfactants in microemulsions because they offer more advantages over conventional surfactants regarding the process of forming a strong interface by virtue of the preferable interactions that occur between the cation and anion. Originally, researchers were trying to solubilize different ILs substituting water from the core of the microemulsions. Subsequently, it was validated that IL can act as an organic solvent as well; besides, water and oil can be dissolved in IL-based surfactant (Kuchlyan et al., 2016). Microemulsions using 1-hexadecyl-3methylimidazolium chloride $\left(\left[\mathrm{C}_{16} \mathrm{MIM}\right] \mathrm{Cl}\right)$ as a surfactant, decanol as co-surfactant, dodecane as nonpolar media and RTILs (ethyl-ammonium nitrate (EAN) and 1-butyl-3-methylimidazolium tetrafluoroborate [BMIM] $\left[\mathrm{BF}_{4}\right]$ have been reported (Zech et al., 2009). Rojas et al. (2013) showed that the IL-in oil microemulsion can be formulated using 1-butyl-3methylimidazoliumdodecylsulfate ([BMIM] $\left[\operatorname{DodSO}_{4}\right]$ ) as SAILs, toluene as non-polar solvent and 1-ethyl-3methylimidazolium ethyl sulfate ([EMIM] $\left[\mathrm{EtSO}_{4}\right]$ ) as polar solvents.

\subsection{Ionic liquids enzyme-catalyzed reactions for halal food industry}

The most generally known enzymes utilized in the food industry are either plant- or animal-based or are obtained via fermentation processes using an array of microbes. In this regard, enzyme manufacturers have a 
great opportunity in the halal market through producing halal certified enzymes and exploring substitutes to animal derived enzymes appropriate for halal food industry (Ermis, 2017). Some enzymes that are required to process food such as lactase for processing milk into lactose-free milk do not pose an issue if they are generated form GRAS microorganisms. However, enzymes may jeopardize the product's halal status if they are attained from non-halal sources or produced using non-halal or doubtful sources (Ermis, 2017). In this paper, our focus is enzyme-catalyzed reactions in ILs.

Various enzymatic synthesis and hydrolysis reactions in ILs media have been reported and in most cases with exceptional yields (Nara et al., 2002; Singh et al., 2010; Sivapragasam et al., 2016). Lipases are one of the large contributors of enzymes in industrial applications due to their multifunctional ability. For example, lipase catalyzes synthesis, hydrolysis as well as polymerization reactions, hence, various products can be obtained in ILs media (Zhao, 2016). Many esters and polyesters are used in food flavoring, as additives, in soap formation or in packaging materials. Flavor esters are substantial and adaptable compounds, commonly used as essential ingredients in foods, drinks, beauty products, medicines, chemicals and other personal care products, such as perfumes, body lotions, face creams and shampoos, because of their scent and flavor. Esters are generally attained through a direct extraction process from plant- or fruit-based sources; however, the yield is inadequate for industrial applications including, hence, chemical synthesis of esters is needed (Almeida et al., 2017).

Ferulic acid and its derivatives are known for their application in the cosmetic and food industries due to of its physiological functions, including antithrombotic, anti -inflammatory, antimicrobial and antioxidative properties. Lauryl ferulate (LF) was produced through catalyzed esterification of fatty acid with lauryl alcohol using lipase in a novel IL medium, (1-(2-(2 methoxyethoxy) ethyl)-5,6,7,8-tetrahydroimidazo[1,2-a] pyridin-1-ium bis(trifluoromethylsulfonyl)amide), ([(EO)-3C-im] $\left.\left[\mathrm{NTf}_{2}\right]\right)$, with LF maximum yield of 90.1\% (Shi et al., 2017).

Quinoline derivatives are of great medical interest with a wide range of antimicrobial, anticancer and antifungal activities. They can be used as additives to suppress the food prone microbes. The synthesis of quinoline derivatives via the $\alpha$-chymotrypsin-catalyzed Friedländer reaction was developed using a convenient and eco-friendly biocatalytic approach. Higher catalytic activity of $\alpha$-chymotrypsin and excellent yield were achieved in [EMIM] $\left[\mathrm{BF}_{4}\right]$ aqueous solution (Le et al.,
2017)

\section{Ionic liquids in food packaging}

Both scientific and industrial entities are increasingly aware of the usage of renewable materials. In this context, tremendous efforts are made in developing sustainable and biodegradable materials from biopolymers to oust traditional non-recyclable materials. In relevance to halalan tayyiban concept, we are encouraged to develop and preserve the Earth to be a sustainable place for future generations. Consequently, green packaging is one of the industry's concerns, and this includes the concern of halal industry. There are several reports on using ILs in packaging.

Construction of gelatin-based ionogel films was conducted using choline salicylate, a bio-based IL to introduce antioxidant and antimicrobial properties in the film. The films have displayed superb antimicrobial, antioxidant properties, outstanding mechanical strength and UV shielding properties. Interestingly, the film demonstrated an excellent applicability for food packaging by averting air oxidation of Malus pumila (Mehta and Kumar, 2019) (Figure 3).

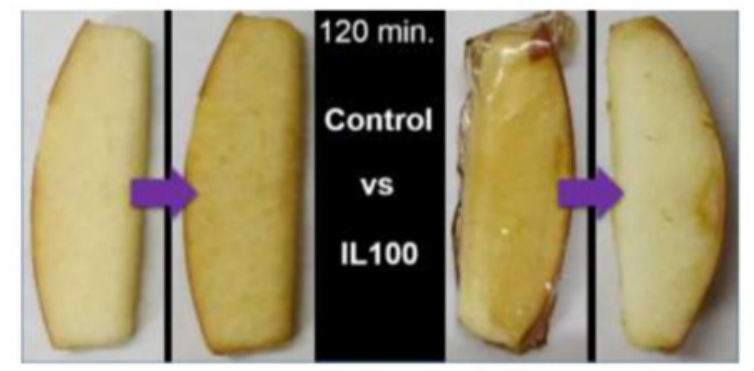

Figure 3. Food preservation test of peeled apple piece using gelatin-based ionogel films (Mehta and Kumar, 2019).

Modification of corn starch by IL lipase-catalyzed esterification involves acylation of hydroxyl groups of glucose units to form starch esters. The reaction was performed using $\left[\mathrm{C}_{16}-3-\mathrm{C}_{16} \mathrm{IM}\right] \mathrm{Br}_{2}$. The modified starch showed better hydrophobic and thermoplastic properties to expand the applications in food and biopolymer sectors (Adak and Banerjee, 2016).

Long-chain cellulose esters are used as biodegradable plastics, film materials and packaging materials. Catalyzed synthesis of long-chain cellulose esters using lipase in mixed ILs, [BMIM]Cl and 1-butyl3 -methylimidazolium tetrafluoroborate, $[\mathrm{BMIM}]\left[\mathrm{BF}_{4}\right]$ in a certain ratio has been reported. Not only this provided a green approach for biodegradable plastic synthesis, but it also enhanced the activity of Candida rugosa lipase in IL and reduced the time required for the cellulose ester formation (Wang et al., 2017). 


\section{Ionic liquids in biosensors and electrolytes applications}

Halal certification is a major concern particularly in food and beverages. Therefore, establishing and enhancing systematic methods for halal authentication is essential to keep Muslim consumers off from prohibited (haram) and doubtful (shubhah) products and to guarantee product safety and quality. Traditional methods, such as HPLC, GC-MS and FTIR have been used for food analysis, however, the process is very tedious and time-consuming as well as requiring skilled person to operate. Hence, developing alternative methods for the identification of non-halal ingredients and contaminants through sensors, for instance is very useful

ILs encompass various advantageous characteristics such as wide electrochemical windows, high intrinsic conductivity and good solvating ability and good thermal stability, which allow them to be useful as non-volatile electrolytes in electrochemical sensors (Silvester, 2011). For instance, a new and altered glassy carbon (GC)based electrode has been prepared and characterized electrochemically for its application in electroanalytical chemistry. The GC was modified with multi-walled carbon nanotubes (MWCNTs), and $\mathrm{TiO}_{2}$ nanoparticles, and combined with a new generation of eco-friendly room-temperature ILs (RTILs), namely choline phenylalanine [Cho][Phe]. The modified electrode was used as substrates for the formation of two enzymatic biosensors for analytical applications; (1) Alcohol dehydrogenase $(\mathrm{ADH})$ for the analysis of ethyl alcohol (2) Lipase enzyme for the analysis and the classification of extra virgin olive oil (EVOO) (Zappi et al., 2019). O'Mahoney et al. (2008), have established a $\mathrm{SO}_{2}$ gas sensor that resembles the Clark model which employs an IL (imidazolium- $\mathrm{Tf}_{2} \mathrm{~N}$ ) as the electrolyte while Wang and co-researchers have described a supported IL membrane-coated oxygen sensor, incorporating ([EMIM] $\left.\left[\mathrm{BF}_{4}\right]\right)$ into a polyethylene membrane (Wang et al., 2003).

A new water-based sensor for $\mathrm{CO}_{2}$ containing [EMIM]Cl, was introduced by Perez et al. (2017). The sensor is based on the $\mathrm{CO}_{2}$ acidity. The most important property for the sensor is stability, as it is intended for smart food packaging, and this has been studied under different conditions of temperature, humidity and light. The sensor was stable for more than 14 days, which is the period required for the application. The production of $\mathrm{CO}_{2}$ was studied simultaneously with total bacterial counts over 14 days for pork meat. The results showed that the $\mathrm{CO}_{2}$ concentration increases in time, and is correlated with bacterial counts. The sensor has been optimized for detection around this concentration, as the threshold of $\mathrm{CO}_{2}$ content for human consumption of this meat is 20\% (Perez et al., 2017). Due to their tunable properties, ILs hold bright future of sensors development for many other applications, such as detection of oils and fats and alcohol. This will indeed aid in the development of halal authentication for rapid analysis.

\section{Ionic liquids in detection of food analysis}

Determination and quantification of desired or restricted compound by food law are essential in food analysis and in halal authentication. However, the process still requires further improvement, especially in term of efficiency, sensitivity and cost. ILs have been popular alternative in the verification of unwanted compounds, for example, in the case of preservatives or heavy metals and even pesticides in food (Hijo et al., 2016). Those compounds are not only toxic, but rather classified as 'haram' (prohibited) due to their toxicity. Food samples consist of broad range of chemical substances and this make them complicated matrices from an analytical point of view. Analytical determination of food sampling and preparation of food samples are usually time consuming and also labor intensive, also required relatively large quantity of organic solvents, even though the most advanced analytical techniques are used (Martín-Calero et al., 2011). In this context, the development of analytical methods for detection is a necessity to claim the product is halalan tayyiban.

For instance, $\mathrm{Tf}_{2} \mathrm{~N}$ anion-based ILs, specifically methylimidazolium bis(trifluoromethylsulfonyl)amide $[\mathrm{OMIM}]\left[\mathrm{Tf}_{2} \mathrm{~N}\right]$ and dispersive liquid-liquid microextraction can successfully extract organophosphorus pesticides in wheat samples by using ultrasonic-assisted combined with HPLC analysis (Liu et al., 2018). Usually, the method used for the extraction of pesticide residue in food is liquid-liquid extraction and supercritical fluid extraction. In recent years, the method used is dispersive liquid-liquid microextraction, which is a simpler method but used toxic and hazardous solvent, which reduced its desirability in compliant with halalan tayyiban. Using ILs, the method is improved and has been noted to be time saving, simple but efficient with high sensitivity and reliability and benign. This is a promising approach to be used for the trace determination of many organic compounds in food industry (Liu et al., 2018).

Metal detection in food is also vital in food analysis. Although some of the metals have nutritional value in very small quantity, metals can be toxic if the limit is exceeded, hence become harmful. This is why the detection of the concentration of metal is important in food quality assurance (Hijo et al., 2016). Khani and 
Shemirani (2013) have done research on monitoring cobalt and nickel in water streams using 1-hexyl-3methylimmidazolium bis-(trifluormethylsulfonyl) amide $\left(\left[\mathrm{C}_{6} \mathrm{MIM}\right]\left[\mathrm{Tf}_{2} \mathrm{~N}\right]\right)$. They observed that the low IL concentration, cost, environmental and toxicological aspects are better than other methods such as solid phase extraction. Ping et al. (2012) found that carbon composite electrode using a combination of bismuth oxide nanoparticles and the IL (n-octylpyridinium hexafluorophosphate) can be utilized to detect cadmium and lead levels in milk at the same time. In the study, it is shown that the altered electrode was subtle, stable and efficient in determining and tracing the presence of heavy metals in trial milk sample analyses.

In food law, antibiotics are either not allowed or the amount should be restricted. Antibiotics are used in the treatment of infections or diseases in animals, and this can cause a risk in the utilization of raw materials such as milk or meat. Therefore, food samples should be tested for the presence of antibiotics before they are ready for human consumption. Gao et al. (2011) have used the ionic liquid, 1-ethyl-3-methylimidazolium [EMIM] $\left[\mathrm{BF}_{4}\right]$ to detect antibiotic in milk. Yang et al. (2014) studied the determination of antibiotics, namely, tetracycline, oxytetracycline and chloramphenicol in honey using the ionic liquid, 1-octyl-3methylimidazolium bromide [OMIM]Br. Shahriari et al. (2013) successfully showed that cholinium-based ILs combined with different chlorate and amino acids can be used for the separation and determination of antibiotics by using aqueous biphasic system followed by spectroscopy.

In food legislations, food additives and preservatives can be used in limited quantity to prolong the shelf life of foods by inhibiting the growth of pathogens or spoilage microorganisms for safe consumption. Sun et al. (2014) detected preservatives in soft drinks by using capillary electrophoresis method using [BMIM] $\mathrm{Cl}$ for a successful determination of three organic acid preservatives, namely, $p$-hydroxybenzoic acid, sorbic acid and cinnamic acid in orange juice and tea drinks. Knowing their levels in foods is crucial for food safety, either in the case of growth of pathogens when below the limits or due to their toxicity when above the limits.

Food adulteration is an illegal practice where adulterants are deliberately mixed to food or vital substance in food is removed, to decrease the food production cost is also an important part in food analysis. Both food consumers and suppliers depend on efficient analysis of the detection of food adulteration. Calvano et al. (2012) developed a technique to detect adulteration regarding extra virgin olive oil using tributylammonium $\alpha$-cyano-4-hydroxycinnamate ([TBA] [CHCA]) for liquid-liquid pre-extraction followed by mass spectrometry. The technique was based on the determination of phospholipids which is highly efficient to detect samples with $1 \%$ of contaminants. This might also work with detection of halal (lawful) and haram (unlawful) substances in food samples. Table 2 summarizes a few ILs that have been used in food analysis.

\section{Conclusion}

Introducing ILs in halal food industry is promising with a large window of applications. ILs can be good replacements for traditional organic solvents in many extraction processes as they minimize the environmental impact and can be recycled. ILs are also suitable media for enzymatic reactions which include but not limited to ester synthesis, polymerization, and other organic isomerization. ILs serve as electrolytes with extraordinary conductivity and physicochemical properties, hence enabling their applications in biosensors for halal authentication. Moreover, the new

Table 2. ILs that have been used for detection in food analysis.

\begin{tabular}{|c|c|c|c|c|}
\hline Sample & Detection & Method & Ionic liquid & References \\
\hline $\begin{array}{l}\text { Food packaging } \\
\text { material }\end{array}$ & Bisphenol A (BPA) & $\begin{array}{l}\text { Solid phase extraction } \\
\text { adsorbent/fluorescence } \\
\text { spectroscopy }\end{array}$ & $\begin{array}{l}\text { 1-octyl-3-methylimidazolium } \\
\text {-hexafluorophosphate }\end{array}$ & $\begin{array}{l}\text { (Liu and Zhu, } \\
\text { 2016) }\end{array}$ \\
\hline Food condiments & $\begin{array}{l}\text { Dyes (chrysoidin, safranine } \\
\text { O, auramine O and } \\
\text { rhodamine B) }\end{array}$ & $\begin{array}{l}\text { IL-based matrix solid-phase } \\
\text { dispersion homogeneous } \\
\text { liquid-liquid microextraction } \\
\text { Immobilized IL in solid- }\end{array}$ & $\begin{array}{l}\text { 1-octyl-3-methylimidazolium } \\
\text { bromide }\end{array}$ & $\begin{array}{l}\text { (Wang et al., } \\
\text { 2014) }\end{array}$ \\
\hline $\begin{array}{l}\text { Bread crust and } \\
\text { cracker samples }\end{array}$ & Trace acrylamide & $\begin{array}{l}\text { phase extraction/high- } \\
\text { performance liquid } \\
\text { chromatography }\end{array}$ & $\begin{array}{l}\text { 1-butyl-3-methylimidazolium } \\
\text { hexafluorophosphate }\end{array}$ & $\begin{array}{l}\text { (Zhao et al., } \\
\text { 2014) }\end{array}$ \\
\hline $\begin{array}{l}\text { Fruit and vegetable } \\
\text { samples }\end{array}$ & Linuron & $\begin{array}{l}\text { IL- loaded } \beta \text {-cyclodextrin } \\
\text { cross-linked polymer (IL- } \beta \text { - } \\
\text { CDCP)/ultraviolet } \\
\text { spectrophotometry }\end{array}$ & $\begin{array}{l}\text { 1-hexyl-3-methylimidazolium } \\
\text { hexafluorophosphate } \\
\left(\left[\mathrm{C}_{6} \mathrm{MIM}\right]\left[\mathrm{PF}_{6}\right]\right)\end{array}$ & $\begin{array}{l}\text { (Feng et al., } \\
\text { 2015) }\end{array}$ \\
\hline Soybean & $\begin{array}{l}\text { Triazine herbicides, including } \\
\text { terbumeton, terbuthylazine, } \\
\text { dimethametryn and } \\
\text { dipropetryn }\end{array}$ & $\begin{array}{l}\text { IL foam-based solvent } \\
\text { flotation/high-performance } \\
\text { liquid chromatography }\end{array}$ & $\left(\left[\mathrm{C}_{6} \mathrm{MIM}\right]\left[\mathrm{PF}_{6}\right]\right)$ & $\begin{array}{c}\text { (Zhang et al., } \\
\text { 2015) }\end{array}$ \\
\hline
\end{tabular}


generations of ILs are derived from natural components such as amino acids and pharmaceutical ingredients. Thus far, no sufficient evidence is available on ILs toxicity in the targeted food products; however, no cell damage was reported in low doses of ILs in vitro and animal tests. Further studies in food applications are necessary to ensure safety and compatibility of ILs in these processes, particularly for human consumption. With rising interests and studies in ILs, it might be a bright future for ILs to be versatile solvents in halal industry, as it can be in accordance with halalan tayyiban principles.

\section{Acknowledgments}

We are grateful to the Ministry of Education, Malaysia, for funding this project through grant no. FRGS19-027-0635.

\section{References}

Adak, S. and Banerjee, R. (2016). A green approach for starch modification: Esterification by lipase and novel imidazolium surfactant. Carbohydrate Polymers, 150, 359-368. https://doi.org/10.1016/ j.carbpol.2016.05.038

Ahmad, I., Yanuar, A., Mulia, K. and Mun'im, A. (2017). Optimization of ionic liquid-based microwave-assisted extraction of polyphenolic content from Peperomia pellucida (L) kunth using response surface methodology. Asian Pacific Journal of Tropical Biomedicine, 7(7), 660-665. https://doi.org/10.1016/J.APJTB.2017.06.010

Ali, M.K., Moshikur, R.M., Wakabayashi, R., Tahara, Y., Moniruzzaman, M., Kamiya, N. and Goto, M. (2019). Synthesis and characterization of cholinefatty-acid-based ionic liquids: A new biocompatible surfactant. Journal of Colloid and Interface Science, 551, 72-80. https://doi.org/10.1016/ j.jcis.2019.04.095

Bapat, A.P., Erck, R., Seymour, B.T., Zhao, B. and Cosimbescu, L. (2018). Lipophilic polymethacrylate ionic liquids as lubricant additives. European Polymer Journal, 108, 38-47. https:// doi.org/10.1016/j.eurpolymj.2018.08.026

Benzagouta, M.S., AlNashef, I.M., Karnanda, W. and Al -Khidir, K. (2013). Ionic liquids as novel surfactants for potential use in enhanced oil recovery. Korean Journal of Chemical Engineering, 30(11), 21082117. https://doi.org/10.1007/s11814-013-0137-1

Bera, A. and Belhaj, H. (2016). Ionic liquids as alternatives of surfactants in enhanced oil recovery-A state-of-the-art review. Journal of Molecular Liquids, 224(Part A), 177-188. https:// doi.org/10.1016/j.molliq.2016.09.105

Calvano, C.D., Ceglie, C. De, D'Accolti, L. and Zambonin, C.G. (2012). MALDI-TOF mass spectrometry detection of extra-virgin olive oil adulteration with hazelnut oil by analysis of phospholipids using an ionic liquid as matrix and extraction solvent. Food Chemistry, 134(2), 11921198.

j.foodchem.2012.02.154

https://doi.org/10.1016/

Choi, S.-A., Lee, J.-S., Oh, Y.-K., Jeong, M.-J., Kim, S.W. and Park, J.-Y. (2014). Lipid extraction from Chlorella vulgaris by molten-salt/ionic-liquid mixtures. Algal Research, 3(1), 44-48. https:// doi.org/10.1016/j.algal.2013.11.013

Cláudio, A.F.M., Ferreira, A.M., Freire, M.G. and Coutinho, J.A.P. (2013). Enhanced extraction of caffeine from guaraná seeds using aqueous solutions of ionic liquids. Green Chemistry, 15(7), 2002. https://doi.org/10.1039/c3gc40437d

Dar, H. and Nursofiza Azmi, R.R. (2010). Global Halal Industry: An Overview. In Global Islamic Finance Report 2013., p. 140-159. Retrieved from http:// www.gifr.net/gifr2013/ch_13.PDF

de Oliveira, N.S., da Carlos, A.L.S., Mattedi, S., Soares, C.M.F., Souza, R.L., Fricks, A.T. and Lima, Á.S. (2018). Ionic liquid-based ultrasonic-assisted extraction of alkaloids from cacao (Theobroma cacao). Chemical Engineering Transactions, 64, 4954. https://doi.org/10.3303/CET1864009

Dhar, A., Kumar, N.S., Sarkar, K., Al-Fatesh, A.S., Ibrahim, A.A., Fakeeha, A.H. and Vekariya, R.L. (2019). Acidic ionic liquids containing variable cationic head groups for catalytic isomerization of nhexane. Journal of Molecular Liquids, 288, 111047. https://doi.org/https://doi.org/10.1016/ j.molliq.2019.111047

Du, F.-Y., Xiao, X.-H. and Li, G.-K. (2007). Application of ionic liquids in the microwave-assisted extraction of trans-resveratrol from Rhizma Polygoni Cuspidati. Journal of Chromatography A, 1140(1-2), 56-62. https://doi.org/10.1016/j.chroma.2006.11.049

Ermis, E. (2017). Halal status of enzymes used in food industry. Trends in Food Science and Technology, 64, 69-73. https://doi.org/10.1016/j.tifs.2017.04.008

Feng, G., Ping, W., Qin, X.X., Liu, J. and Zhu, X. (2015). Ionic-Liquid-Loaded $\beta$-Cyclodextrin-CrossLinked Polymer Solid-Phase Extraction for the Separation/Analysis of Linuron in Fruit and Vegetable Samples. Food Analytical Methods, 8(9), 2315-2320. https://doi.org/10.1007/s12161-0150118-6

Guolin, H., Jeffrey, S., Kai, Z. and Xiaolan, H. (2012). 
Application of Ionic Liquids in the MicrowaveAssisted Extraction of Pectin from Lemon Peels. Journal of Analytical Methods in Chemistry, 2012, 1 -8. https://doi.org/10.1155/2012/302059

Ji, Y., Hou, Y., Ren, S., Yao, C. and Wu, W. (2018). Highly efficient extraction of phenolic compounds from oil mixtures by trimethylamine-based dicationic ionic liquids via forming deep eutectic solvents. Fuel Processing Technology, 171, 183191. https://doi.org/10.1016/j.fuproc.2017.11.015

Kuchlyan, J., Kundu, N. and Sarkar, N. (2016). Ionic liquids in microemulsions: Formulation and characterization. Current Opinion in Colloid and Interface Science, 25, 27-38. https://doi.org/10.1016/ j.cocis.2016.05.011

Lago, S., Rodríguez, H., Khoshkbarchi, M.K., Soto, A. and Arce, A. (2012). Enhanced oil recovery using the ionic liquid trihexyl(tetradecyl)phosphonium chloride: phase behaviour and properties. RSC Advances, 2(25), 9392. https://doi.org/10.1039/ c2ra21698a

Le, Z.G., Liang, M., Chen, Z.S., Zhang, S.H. and Xie, Z.B. (2017). Ionic liquid as an efficient medium for the synthesis of quinoline derivatives via $\alpha$ chymotrypsin-catalyzed friedländer condensation. Molecules, 22(5), 762. https://doi.org/10.3390/ molecules22050762

Lee, S.Y., Khoiroh, I., Coutinho, J.A.P., Show, P.L. and Ventura, S.P.M. (2017). Lipase production and purification by self-buffering ionic liquid-based aqueous biphasic systems. Process Biochemistry, 63, 221-228. https://doi.org/https://doi.org/10.1016/ j.procbio.2017.08.020

Liu, J. and Zhu, X. (2016). Ionic Liquid-Immobilized Expanded Perlite Solid-Phase Extraction for Separation/Analysis of Bisphenol A in Food Packaging Material. Food Analytical Methods, 9(3), 605-613. https://doi.org/10.1007/s12161-015-0222-7

Liu, W., Quan, J. and Hu, Z. (2018). Detection of Organophosphorus Pesticides in Wheat by Ionic Liquid-Based Dispersive Liquid-Liquid Microextraction Combined with HPLC. Journal of Analytical Methods in Chemistry, 2018, 1-10. https://doi.org/10.1155/2018/8916393

Lu, Y., Ma, W., Hu, R., Dai, X. and Pan, Y. (2008). Ionic liquid-based microwave-assisted extraction of phenolic alkaloids from the medicinal plant Nelumbo nucifera Gaertn. Journal of Chromatography A, 1208(1-2), 42-46. https:// doi.org/10.1016/j.chroma.2008.08.070

Lunagariya, J., Dhar, A. and Vekariya, R.L. (2017). Efficient esterification of n-butanol with acetic acid catalyzed by the Brönsted acidic ionic liquids: influence of acidity. RSC Advances, 7(9), 54125420. https://doi.org/10.1039/C6RA26722J

Lunagariya, J., Kumar, N.S., Asif, M., Dhar, A. and Vekariya, R.L. (2017). Dependency of anion and chain length of imidazolium based ionic liquid on micellization of the block copolymer F127 in aqueous solution: An experimental deep insight. Polymers, 9(7), 285. https://doi.org/10.3390/ polym 9070285

Ma, W., Lu, Y., Hu, R., Chen, J., Zhang, Z. and Pan, Y. (2010). Application of ionic liquids based microwave-assisted extraction of three alkaloids Nnornuciferine, $\mathrm{O}$-nornuciferine, and nuciferine from lotus leaf. Talanta, 80(3), 1292-1297. https:// doi.org/10.1016/j.talanta.2009.09.027

Martín-Calero, A., Pino, V. and Afonso, A.M. (2011). Ionic liquids as a tool for determination of metals and organic compounds in food analysis. TrAC Trends in Analytical Chemistry, 30(10), 1598-1619. https://doi.org/10.1016/J.TRAC.2011.04.023

Martins, P.L.G., Braga, A.R. and de Rosso, V.V. (2017). Can ionic liquid solvents be applied in the food industry? Trends in Food Science and Technology, 66, 117-124. https://doi.org/10.1016/ j.tifs.2017.06.002

Mehta, M.J. and Kumar, A. (2019). Ionic Liquid Assisted Gelatin Films: Green, UV Shielding, Antioxidant, and Antibacterial Food Packaging Materials. ACS Sustainable Chemistry and Engineering, 7(9), 8631-8636. https:// doi.org/10.1021/acssuschemeng.9b00423

Michalczyk, A., Cieniecka-Roslonkiewicz, A. and Cholewinska, M. (2015). Application of Ionic Liquids in the Ultrasound-Assisted Extraction of Antimicrobial Compounds from the Bark of Cinnamomum Cassia. Journal of the Chilean Chemical Society, 60(4), 2698-2703. https:// doi.org/10.4067/S0717-97072015000400013

Mizumo, T., Watanabe, T. and Ohno, H. (2008). Thermally Stable and Proton Conductive Ionogel Based on Brønsted Acidic Ionic Liquid with the Support of Silicate Network. Polymer Journal, 40 (11), 1099-1104. https://doi.org/10.1295/ polymj.pj2008153

Mohajeri, E. and Noudeh, G.D. (2012). Effect of Temperature on the Critical Micelle Concentration and Micellization Thermodynamic of Nonionic Surfactants: Polyoxyethylene Sorbitan Fatty Acid Esters. E-Journal of Chemistry, 9(4), 2268-2274. https://doi.org/10.1155/2012/961739

Pan, J., Muppaneni, T., Sun, Y., Reddy, H.K., Fu, J., Lu, 
X. and Deng, S. (2016). Microwave-assisted extraction of lipids from microalgae using an ionic liquid solvent [BMIM][HSO4]. Fuel, 178, 49-55. https://doi.org/10.1016/j.fuel.2016.03.037

Perez de Vargas-Sansalvador, I.M., Erenas, M.M., Diamond, D., Quilty, B. and Capitan-Vallvey, L.F. (2017). Water based-ionic liquid carbon dioxide sensor for applications in the food industry. Sensors and Actuators B: Chemical, 253, 302-309. https:// doi.org/https://doi.org/10.1016/j.snb.2017.06.047

Pinkert, A., Marsh, K.N., Pang, S. and Staiger, M.P. (2009). Ionic liquids and their interaction with cellulose. Chemical Reviews, 109(12), 6712-6728.

Qin, H., Zhou, G., Peng, G., Li, J. and Chen, J. (2015). Application of Ionic Liquid-Based UltrasoundAssisted Extraction of Five Phenolic Compounds from Fig (Ficus carica L.) for HPLC-UV. Food Analytical Methods, 8(7), 1673-1681. https:// doi.org/10.1007/s12161-014-0047-9

Rajapriya, G., Morya, V.K., Mai, N.L. and Koo, Y.-M. (2019). Aspergillus niger whole-cell catalyzed synthesis of ca ff eic acid phenethyl ester in ionic liquids. Enzyme and Microbial Technology., 11, 6773. https://doi.org/10.1016/j.enzmictec.2017.10.005

Rojas, O., Tiersch, B., Rabe, C., Stehle, R., Hoell, A., Arlt, B. and Koetz, J. (2013). Nonaqueous Microemulsions Based on $N, N^{\prime}$-Alkylimidazolium Alkylsulfate Ionic Liquids. Langmuir, 29(23), 68336839. https://doi.org/10.1021/la401080q

SÁ, A.G.A., Meneses, A.C.D., Araújo, P.H.H.D. and Oliveira, D.D. (2017). A review on enzymatic synthesis of aromatic esters used as flavor ingredients for food, cosmetics and pharmaceuticals industries. Trends in Food Science and Technology, 69(Part A), 95-105. https://doi.org/10.1016/ j.tifs.2017.09.004

Sazelin, A., Ridzwan, A., Arif, S. and Ahmad, R. (2011). Food quality standards in developing quality human capital: An Islamic perspective. African Journal of Business Management, 5(31), 12242-12248. https:// doi.org/10.5897/AJBM10.1692

Shi, Y., Wu, Y., Lu, X., Ren, Y., Wang, Q., Zhu, C.-M., $\mathrm{Yu}$, D. and Wang, H. (2017). Lipase-catalyzed esterification of ferulic acid with lauryl alcohol in ionic liquids and antibacterial properties in vitro against three food-related bacteria. Food Chemistry, 220, 249-256. https://doi.org/https://doi.org/10.1016/ j.foodchem.2016.09.187

Silvester, D.S. (2011). Recent advances in the use of ionic liquids for electrochemical sensing. Analyst, 136(23), 4871-4882. https://doi.org/10.1039/ c1 an15699c
Sivapragasam, M., Moniruzzaman, M. and Goto, M. (2016). Recent advances in exploiting ionic liquids for biomolecules: Solubility, stability and applications. Biotechnology Journal, 11, 1000-1013.

Sun, X., Jin, Z., Yang, L., Hao, J., Zu, Y., Wang, W. and Liu, W. (2013). Ultrasonic-Assisted Extraction of Procyanidins Using Ionic Liquid Solution from Larix gmelinii Bark. Journal of Chemistry, 2013, 1-9. https://doi.org/10.1155/2013/541037

Tateishi-Karimata, H. and Sugimoto, N. (2018). Biological and nanotechnological applications using interactions between ionic liquids and nucleic acids. Biophysical Reviews, 10(3), 931-940. https:// doi.org/10.1007/s12551-018-0422-7

Toledo Hijo, A.A.C., Maximo, G.J., Costa, M.C., Batista, E.A.C. and Meirelles, A.J.A. (2016). Applications of Ionic Liquids in the Food and Bioproducts Industries. ACS Sustainable Chemistry and Engineering, 4(10), 5347-5369. https:// doi.org/10.1021/acssuschemeng.6b00560

Vekariya, R.L. (2017). A review of ionic liquids: Applications towards catalytic organic transformations. Journal of Molecular Liquids, 227, 44-60. https://doi.org/https://doi.org/10.1016/ j.molliq.2016.11.123

Ventura, S.P.M., e Silva, F.A., Quental, M.V., Mondal, D., Freire, M.G. and Coutinho, J.A.P. (2017). IonicLiquid-Mediated Extraction and Separation Processes for Bioactive Compounds: Past, Present, and Future Trends. Chemical Reviews, 117(10), 6984 -7052. https://doi.org/10.1021/acs.chemrev.6b00550

Vicente, F.A., Lario, L.D., Pessoa, A. and Ventura, S.P.M. (2016). Recovery of bromelain from pineapple stem residues using aqueous micellar twophase systems with ionic liquids as co-surfactants. Process Biochemistry, 51(4), 528-534. https:// doi.org/10.1016/J.PROCBIO.2016.01.004

Wang, F., Zhao, G., Lang, X., Li, J. and Li, X. (2017). Lipase-catalyzed synthesis of long-chain cellulose esters using ionic liquid mixtures as reaction media. Journal of Chemical Technology and Biotechnology, 92(6), 1203-1210. https://doi.org/10.1002/jctb.5109

Wang, R., Hoyano, S. and Ohsaka, T. (2003). O2 Gas Sensor Using Supported Hydrophobic Roomtemperature Ionic Liquid Membrane-coated electrode. Chemistry Letters, 33(1), 6-7. https:// doi.org/10.1246/c1.2004.6

Wang, Z., Zhang, L., Li, N., Lei, L., Shao, M., Yang, X., Song, Y., Yu, A., Zhang, H. and Qiu, F. (2014). Ionic liquid-based matrix solid-phase dispersion coupled with homogeneous liquid-liquid microextraction of synthetic dyes in condiments. 
Journal of Chromatography A, 1348, 52-62. https:// doi.org/10.1016/j.chroma.2014.04.086

Xu, W., Chu, K., Li, H., Zhang, Y., Zheng, H., Chen, R. and Chen, L. (2012). Ionic Liquid-Based Microwave -Assisted Extraction of Flavonoids from Bauhinia championii (Benth.) Benth. Molecules, 17(12), 14323-14335. molecules171214323

https://doi.org/10.3390/

Young, G., Nippgen, F., Titterbrandt, S. and Cooney, M.J. (2010). Lipid extraction from biomass using cosolvent mixtures of ionic liquids and polar covalent molecules. Separation and Purification Technology, 72(1), 118-121. https://doi.org/10.1016/ j.seppur.2010.01.009

Zappi, D., Gabriele, S., Gontrani, L., Dini, D., Sadun, C., Marini, F. and Antonelli, M.L. (2019). Biologically friendly room temperature ionic liquids and nanomaterials for the development of innovative enzymatic biosensors: Part II. Talanta, 194, 26-31. https://doi.org/10.1016/j.talanta.2018.10.001

Zech, O., Thomaier, S., Bauduin, P., Rück, T., Touraud, D. and Kunz, W. (2009). Microemulsions with an Ionic Liquid Surfactant and Room Temperature Ionic Liquids As Polar Pseudo-Phase. The Journal of Physical Chemistry B, 113(2), 465-473. https:// doi.org/10.1021/jp8061042

Zeng, H., Wang, Y., Kong, J., Nie, C. and Yuan, Y. (2010). Ionic liquid-based microwave-assisted extraction of rutin from Chinese medicinal plants. Talanta, 83(2), 582-590. https://doi.org/10.1016/ j.talanta.2010.10.006

Zhang, L., Yao, D., Yu, R., Li, N., Zhang, H. and Yu, A. (2015). Extraction and separation of triazine herbicides in soybean by ionic liquid foam-based solvent flotation and high performance liquid chromatography determination. Analytical Methods, 7(5), 1977-1983. https://doi.org/10.1039/ C4AY02579B

Zhang, X., Li, X., He, Q., Zhang, B., Zheng, X., Zhang, B. and Zheng, X. (2017). Ionic Liquid Based Ultrasonic-Assisted Extraction of Oleanolic Acid from Grape Seeds. Open Access Library Journal, 4, 1-16. https://doi.org/10.4236/oalib.1104148

Zhang, Y., Zhen, B., Li, H. and Feng, Y. (2018). Basic ionic liquid as catalyst and surfactant: green synthesis of quinazolinone in aqueous media. RSC Advances, 8(64), 36769-36774. https:// doi.org/10.1039/C8RA06378H

Zhao, H. (2016). Protein stabilization and enzyme activation in ionic liquids: specific ion effects. Journal of Chemical Technology and Biotechnology, 91(1), 25-50.
Zhao, H. (2019). Enzymatic polymerization to polyesters in nonaqueous solvents. In Pyle, A.M. and Christianson, D.W. (Eds.) Methods in Enzymology. 1st ed. USA: Academic Press. https:// doi.org/10.1016/bs.mie.2019.03.002

Zhao, H., Dai, B., Xu, L., Wang, X., Qiao, X. and Xu, Z. (2014). Preparation and application of immobilised ionic liquid in solid-phase extraction for determination of trace acrylamide in food samples coupled with high-performance liquid chromatography. Journal of the Science of Food and Agriculture, 94(9), 1787-1793. https:// doi.org/10.1002/jsfa.6493 